\title{
Research on the Innovation of Ideological and Political Education of Colleges and Universities at Micro - times
}

\author{
Yu Liu \\ Heyuan Polytechnic, Ideological and Political Department, Heyuan, Guangdong, China, 517000
}

Keywords: Micro - Era; College Students; Ideological and Political Education

\begin{abstract}
The rapid development of information technology, making We-Chat, micro-blogging and so on to "micro" to name things more up, people thus entered the "micro-era." Micro-era so that people communicate the way information has changed. Nowadays college students have more opportunities to contact new media, their values and ideas have gradually changed, which brings challenges to ideological and political education in colleges and universities. In the micro-era, colleges and universities to do ideological and political education work is very important.
\end{abstract}

\section{Introduction}

Micro-era is in the context of the information age gave birth to a new term, its representative thing is "micro-blogging", "We-Chat" and so on, these new things college students more contact, their values are thinking have a certain impact. Under such circumstances, the ideological and political education in colleges and universities has become an urgent problem to be solved. This article mainly discusses how to improve the ideological and political education in colleges and universities under the background of micro-times.

\section{The Influence of Micro - era on Ideological and Political Education in Colleges and Universities}

Impact on Values. As the Internet continues to spread, people get the way to publish information has become more convenient and people can use the network to achieve these. Although the development of the network is very fast, but its supervision is not in place, the network of various information, which will certainly have some information is negative, these negative information once spread to people's values will have a certain impact [1]. College students to accept new things faster, but the lack of certain ability to distinguish their ability to distinguish between true and false is not high, so easy to be those who have ulterior motives to use to lure them to accept the wrong message, if not at this time they strengthen the guidance of the words, it will make the students to establish the wrong values. These will have a very negative impact on their future growth.

Let the Ideological and Political Teacher into Embarrassment. The development of new media is very fast, many teachers have not used micro-media for teaching, there is no corresponding micro-media awareness and there is no psychological behavior of college students' in-depth and meticulous understanding, resulting in college students' favorite micro-micro Bo and other similar areas in the political education which has become a blank area. Teachers did not notice is that students use micro-blogging to accept the information has been more than the teacher explained the information, because the teachers did not carry out in-depth exploration of micro-media, the lack of understanding of the situation of students, resulting in information is not connected, Students are also not interested in the study of political education. The arrival of the micro-era increased the difficulty of teaching teachers, so that they fall into an embarrassing situation.

Bring Challenge to the Realization of Teaching Objectives. The purpose of ideological and political education for college students is to make students establish the correct three views, in practice to achieve the regulation of moral behavior, shaping the individual personality, stimulate 
the spiritual power, leading the political direction and ecological value, social, economic, political Unity, in simple terms is the unity of individual values and social values [2]. However, from the reality, the ideological and political education in colleges and universities do not attach importance to individual values, in the blind focus on social values do not attach importance to the needs of college students, making a lot of college students have no interest in learning. In the context of the micro-era, a lot of information is based on the students themselves as the center of the spread, they pay more attention to self-development, in such circumstances, if the university in the teaching of ideological and political courses or follow the traditional teaching philosophy, the needs of college students, naturally difficult to obtain student recognition.

Challenges in Teaching Methods. In the teaching of ideological and political courses when instilled is a more classic and commonly used method. In the process of cultivating college students to establish the correct values of this process undeniable indoctrination has a very important role [3]. But in the course of practice but often encountered to hear the forgotten situation, this way will reduce the teaching effect. Micro-era under a variety of new media began to flood in college students on the phone, flat, began in their lives occupy an increasingly important position. Information dissemination in the micro-era is the interaction, the information center is not fixed, naturally there is no so-called "fixed authority", in this context and each student can use the mobile side to carry out the information release, while everyone also can be issued by others to give a reply to the information. In the face of such a lot of information, just rely on the teacher is no way to fully monitor it, in such circumstances, the same content, a set of teaching materials, a teacher is no way to deal with such challenges. How to integrate the complex resources of the Internet, the mobilization of all teachers need to solve a problem.

\section{Analysis of the Opportunities Faced by Ideological and Political Education in Colleges and Universities under the Background of Micro - times}

Emerging media in the micro-era mushroomed and these new media by college students' love, this situation to the ideological and political teachers to increase the difficulty of teaching at the same time also brought some opportunities. Unlike traditional media, the emerging media has some characteristics of interaction, immediacy and so on. College teachers can use these features to realize real-time interaction with students in teaching ideological and political courses, so that they can have a dynamic timely understanding, and then make ideological and political education more effective and targeted.

Enrich the Teaching Content. The use of traditional way of teaching ideological and political education is the idea of teachers spread to the students, teaching content involved in the content is not much [4]. The emerging media in the context of the micro-era has brought great influence to the students' ideological life. They accept that the ideas are no longer limited to the teaching of the teachers. They can use the network channels to obtain all kinds of information, and the content More and more. On the teaching of ideological and political teachers, they should keep up with the pace of the times, the teaching content will be rich, with students familiar with those new media to carry out ideological and political education, so that ideological and political education can show new content, new style, the traditional boring teaching situation to break, to mobilize the enthusiasm of students to learn.

Innovative Educational Methods. The traditional way of teaching ideological and political is too simple, the main method is to use indoctrination, the teacher kept talking on the podium, the students sitting in the following passive listening. Over time will allow students to have a boredom and there is no way to stimulate their enthusiasm to learn out. In the context of the micro-era, the unique advantages of the emerging media can promote the ideological and political education activities to carry out better, new media can innovate education methods, the traditional boring classroom changes, to mobilize students to learn enthusiasm. Teachers need to put students in the main body of the classroom, in the teaching process to implement the people-oriented teaching philosophy, to students to create an interactive, open learning atmosphere. Ideological and political teachers can use We-Chat, micro-blogging and other emerging media as an information carrier to 
the students of various ideological and dynamic grasp, so that the initiative of education is enhanced, and actively guide the correct public opinion, training students to form the correct view of the three.

Reduced Investment in Education. In the past, the traditional model of ideological and political education requires a lot of financial and human resources, the so-called financial resources refers to the expenditure of education and education facilities, etc .; human refers to the teaching activities of teachers [5]. The traditional model of teaching requires a lot of teachers, so that will increase the cost of investment a lot. In the context of micro-era, We-Chat, micro-blogging and other new media in the transmission of information when there is a certain degree of immediacy, and this is a way college students like, which gives teaching ideological and political education provides a convenient a new way of teaching. Under the background of the micro-era teaching teachers of the use of new media not only can make financial and human resources to reduce, but also can break the limitations of time and space to carry out various teaching activities to enhance students' interest in learning.

\section{Analysis of the Ways to Innovate the Mode of Ideological and Political Education in Colleges and Universities in the Context of Micro - times}

Use Micro-Blogging and Other New Media Innovation Teaching Model. Because of the impact of the diversity of ideas, the use of the traditional teaching model to teach the ideological and political access to the effect of getting worse, so the case of ideological and political teaching model innovation has become a must do [6]. The use of various social platforms to carry out ideological and political education is a better way to try. Teachers group from the past that the traditional teaching mode which came out, the use of the creation of forums, micro-public and micro-blogging public information such as those hot spots, current events, educational information and other information forwarded to students. At the same time to listen carefully to their views, for their questions to the teacher to seriously solve the understanding of the students also have a variety of ideological and dynamic in order to give them timely help, intervention and grooming, so that the communication between the school and students get Enhanced.

Teachers in the We-Chat, micro-blogging and other media as a way to communicate with students at the same time to ideological and political courses into the theoretical content of which teachers should encourage students to pay attention to Chinese development process, to deepen their understanding of Mao Zedong Thought and The theory of socialism with Chinese characteristics and other advanced theories of understanding and understanding, so that micro-media social platform can really be used for teaching ideology and politics.

Pay Attention to Media Fit. Colleges and universities in the ideological and political teaching when the introduction of micro-media, which is an innovative attempt has a very significant significance [7]. One of the most important thing is to grasp the scale, in the reform of the teacher is one of the promoters and organizers, so the teacher in the actual teaching time to clear the scope of the application of micro-media there range cannot rely on micro-media To complete all the teaching, this will make the ideological and political education security and stability have been affected. Teachers need to understand the operation of micro-media network to master the law, to the curriculum knowledge and micro-media cooperation in the form of requirements and planning in advance, but also need to do a variety of emergency response measures to ensure the use of micro-media Teaching ideological and political is safe and effective [8]. In addition, the teachers also need to have some teaching skills and strong professional knowledge, in the micro-media teaching time can be contingent, the life of some of the social problems and the political theory to be combined, so as to allow students Improve cognitive ability.

Grasp the Initiative in Teaching. In the context of micro-era, the use of We-Chat, micro-blogging and other micro-media engaged in ideological and political education is closely follow the pace of the times a reflection. Teachers in the teaching process to firmly grasp the initiative to use personal We-Chat, micro-blogging and students to establish an interactive relationship in the process of interaction with the correct public opinion to guide students to guide students to encourage students to create a high faith, to use their own words and deeds to influence 
them, so that they can develop good habits, enhance communication between students and teachers, the establishment of deep feelings, and then lead them to form the correct values.

In addition, teachers need to have a keen observation, to be good at discovering what new things are welcomed by students, to actively accept these new things, and then use it in their own teaching activities, to improve student interest in learning [9]. In the process of using micro-media teaching, the teacher should lower his posture, with equal vision to look at every student, so they are willing to take the initiative to their own ideas and ideas put forward, so teacher in the teaching of the time can be more targeted. Teachers in the usual life to take the initiative to understand the value orientation of each student there are spiritual needs, so that teachers and students can be more harmonious relationship, and thus promote the smooth development of ideological and political education activities.

\section{Conclusion}

In terms of ideological and political education in colleges and universities, the application of micro-media in the context of micro-era is a good teaching method. Not only allow students to be more convenient for self-learning, but also allow teachers to update their educational philosophy as well as teaching methods, and is advancing, and thus promote the ideological and political education activities in the smooth development of teaching quality, but also to stimulate students' interest in learning, so as to be able to better help students to establish the correct three views, to promote the comprehensive development of students, grow up for the needs of the community.

\section{Acknowledgements}

Fund Project: This article is the Guangdong Province Guangdong Education and Teaching Achievement Award (Higher Education) cultivation project (Guangdong Education letter [2015] 72). The stage research results of the Heyuan Vocational and Technical College Education Science Project (subject number 2014-JY15) "Practice education resources development and utilization of 'two cultures' background."

\section{References}

[1] Ruan Bo. "Micro - era" ideological and political theory teaching reform[J]. Ideological and theoretical education, 2016, (07): 63-67.

[2] Chen Huizhen. A Study on the Teaching Innovation of Ideological and Political Theory Course in Colleges and Universities under Micro - era[J]. Journal of Chengdu University of Traditional Chinese Medicine (Educational Science Edition), 2016, (02): 51-53.

[3] Yuan Yuan. "Micro - era" ideological and political theory of teaching reform model [D]. Henan University of Technology, 2016

[4] Xi Lu. "Micro - era" ideological and political education in colleges and universities innovation research[D]. Lanzhou University of Technology, 2016

[5] Wang Liming. Research on the Innovation of Ideological and Political Education in Colleges and Universities in the New Media Age[D]. Henan University, 2016

[6] Chang Sufang. Deviation from the integration: the new media era under the ideological and political education innovation dilemma and digestion [J]. Education Exploration, 2016, (05): 101-104.

[7] Lu Feng, Guan Aihua. Discussion on the Innovative Practice Path of Teaching Reform of Ideological and Political Theory Course in Colleges and Universities under the New Media Environment[J]. Ideological and political education research, 2016, (06): 77-80. 
[8] Gao Xu, Sun Gong. A new bridge between teachers and students after school - "Post - teaching of ideological and political theory" in "micro - era"[J]. Journal of Anhui University of Science and Technology (Social Science Edition), 2016, (05): 99-104.

[9] Chen Qianling, Zhou Changqun. New era of innovation in ideological and political education in colleges and universities[J]. Ideological and Political Education Research, 2014, (03): 57-60. 